\title{
APLIKASI MOL GAMAL PADA PERTUMBUHAN DAN PRODUKSI PADI SAWAH METODE SRI (System of Rice Intensification)
}

\section{APLICATION OF GLIRICIDIA MOL ON GROWTH AND PRODUCTION OF LOWLAND RICE IN THE SRI (System of Rice Intensification) METHOD}

\author{
Jeanne Martje Paulus ${ }^{1)^{*}}$,Jemmy Najoan ${ }^{1)}$ dan Paula C. Supit ${ }^{1)}$ \\ 1)Dosen Jurusan Budidaya Pertanian, Fakultas Pertanian Unsrat Manado, 95115 \\ *) Korespondensi email : jeannepaulus5@gmail.com
}

\begin{abstract}
The aim of the research was to studied the application of gliricidia MOL on the growth and yield of lowland rice in the SRI method, and to get the best time of gliricidia MOL application on the growth and production of lowland rice. Field research has been conducted in Tara-Tara II Village, West Tomohon Subdistrict for five months starting from June 2017 until November 2017. Treatment in the experiment consists of one treatment factor, that was interval time of gliricidia MOL application, ie : $0,5,10,15$, and 20 days. The results showed that time application of gliricidia MOL have an effect on the number of productive tillers, the number of filled grain/panicle, the number of empty grain/panicle, and the dry grain yield (GKP) / plot, but not affect the plant height. The best results were achieved in gliricia MOL application on interval time every 15 days with a values were : 28.66 productive tillers; 176.90 fillet grain/panicle; 19.80 empty grain/panicle (lowest); and $9.50 \mathrm{~kg}$ dry grain yield or equivalent to 7.92 ton/ha.
\end{abstract}

Keywords: gliricidia MOL, production, lowland rice, System of Rice Intensification (SRI)

\section{ABSTRAK}

Penelitian ini bertujuan untuk : (1) mengkaji aplikasi mikroorganisme lokal (MOL) gamal pada pertumbuhan dan hasil padi sawah Metode SRI, (2) mendapatkan waktu aplikasi MOL gamal yang terbaik pada pertumbuhan dan produksi padi sawah Metode SRI. Penelitian lapangan telah dilaksanakan di Desa Tara-Tara II Kecamatan Tomohon Barat selama 5 (lima) bulan dimulai pada bulan Juni 2017 sampai dengan Nopember 2017. Perlakuan dalam percobaan terdiri atas satu faktor perlakuan, yaitu interval waktu aplikasi MOL gamal,: 0, 5, 10, 15, dan 20 hari. Hasil penelitian menunjukkan bahwa interval waktu aplikasi MOL gamal berpengaruh terhadap jumlah anakan produktif, jumlah gabah bernas/malai, jumlah gabah hampa/malai, dan hasil gabah kering panen (GKP)/petak, namun tidak berpengaruh terhadap tinggi tanaman. Hasil terbaik dicapai pada perlakuan waktu aplikasi MOL gamal setiap 15 hari dengan nilai-nilai adalah : 28,66 anakan produktif; 176,90 gabah bernas/malai ; 19,80 gabah hampa/malai (terendah); dan 9,50 kg GKP/petak setara dengan 7,92 ton/ha.

Kata kunci : MOL daun gamal, produksi, padi sawah, System of Rice Intensification (SRI) 


\section{PENDAHULUAN}

Padi merupakan tanaman pangan utama penghasil karbohidrat yang dikonsumsi oleh sebagian besar penduduk Indonesia. Peningkatan jumlah penduduk sejalan dengan peningkatan kebutuhan akan beras, yaitu sekitar 240 juta jiwa penduduk Indonesia menghadapi tantangan yang sangat kompleks dalam memenuhi kebutuhan pangan. Ketergantungan pangan yang bertumpu pada beras sangat tidak menguntungkan bagi kelangsungan ketahanan pangan nasional.

Produksi padi secara nasional maupun regional masih tergolong rendah, dan dari tahun ke tahun tidak mengalami peningkatan yang berarti. Produktivitas padi nasional dari tahun 2011 sampai 2014 berturut-turut adalah 5,13 ton ha-1, 5,31 ton $\mathrm{ha}^{-1}, 5,32$ ton ha-1, 5,29 ton ha-1 ${ }^{-1}$ dan di Sulawesi Utara berturut-turut adalah 5,16 ton ha-1, 5,15 ton ha-1 5,30 ton ha-1 ${ }^{-1}$ dan 5,29 ton ha-1 (Badan Pusat Statistik, 2015). Salah satu penyebab penurunan produktivitas padi adalah selain teknik budidaya yang kurang memadai, juga terjadi penurunan kesuburan lahan sawah sebagai dampak dari penggunaan pupuk kimia dosis tinggi dan dalam kurun waktu yang lama.

Anugrah, dkk. (2008), menyatakan bahwa metode SRI merupakan salah satu pendekatan dalam praktek budidaya padi yang menekankan pada manajemen pengelolaan tanah, tanaman, dan air melalui pemberdayaan kelompok dan kearifan lokal yang berbasis pada kegiatan ramah lingkungan. Menurut Purwasasmita dan Sutaryat (2012), bahwa beberapa implementasi SRI Organik Indonesia, adalah : negara dapat menghemat subsidi pupuk urea, membawa keuntungan atau manfaat terhadap lingkungan karena menghemat penggunaan air, penghilangan emisi gas rumah kaca (metana), meningkatkan produktivitas tanaman padi.

Prinsip dari penerapan metode SRI, sebagai berikut : (1) pananaman bibit pada usia muda, yaitu pada umur 11 hari setelah semai (hss) atau bibit memiliki 2 helai daun; (2) penanaman bibit satu bibit per lobang dengan jarak tanam lebar $30 \mathrm{~cm} \times 30 \mathrm{~cm}, 35 \mathrm{~cm} \times 35 \mathrm{~cm}$ atau $40 \mathrm{~cm} \times 40$ $\mathrm{cm}$; (3) pindah tanam (transplanting) dengan waktu sangat singkat, yaitu kurang dari 30 menit dan harus hati-hati agar akar tidak putus dan ditanam dangkal; (4) pemberian air maksimum $2 \mathrm{~cm}$ (macak-macak) dan pada periode tertentu. Dikeringkan sampai pecah (irigasi berselang/terputus); dan (5) penyiangan dilakukans ejak awal sekitar umur 10 hari dan diulang 2 - 3 kali dengan interval 10 hari.

Di Sulawesi Utara, budidaya padi berbasis organik dengan metode SRI belum diterapkan karena berbagai kendala, antara lain ketersediaan pupuk organik secara kontinu belum terpenuhi, dan petani belum terampil untuk memanfaatkan limbah organik seperti jerami padi, dan sumber bahan organik lainnya (tanaman leguminosa) untuk pembuatan pupuk cair organik/mikroorganisme lokal (MOL).

Mikro organisme lokal (MOL) adalah cairan mikroba perombak yang terbuat dari bahan organik alami mengandung unsur hara makro dan mikro yang berfungsi untuk meningkatkan pertumbuhan dan hasil tanaman serta dapat mengendalikan hama dan penyakit tanaman. Menurut Purwasasmita dan Sutaryat (2012), bahwa larutan MOL memiliki multifungsi, yaitu sebagai dekomposer, pupuk hayati dan pestisida organik (khususnya fungisida), penggunaannya terutama sebagai semaian mikroorganisme pemicu siklus kehidupan. Berbagai hasil penelitian menunjukkan bahwa aplikasi larutan MOL berpengaruh pada pertumbuhan dan produksi tanaman.

Tanaman gamal (Gliricidia sepium) tergolong jenis tanaman leguminosa yang banyak mengandung nitrogen karena jenis tanaman ini dapat mengikat nitrogen bebas dari udara. Unsur nitrogen merupakan hara utama yang dibutuhkan oleh tanaman padi selama pertumbuhannya, disamping hara lainnya seperti fosfor dan kalium. Oleh sebab itu tingkat keefektifan dari larutan MOL khususnya MOL dari daun gamal masih perlu diuji pada tanaman padi dalam upaya untuk meningkatkan produksi padi sawah metode SRI di Kabupaten Minahasa.

Penelitian ini bertujuan untuk : (1) mengkaji pengaruh interval waktu aplikasi mikroorganisme lokal (MOL) gamal pada pertumbuhan dan hasil padi sawah Metode SRI, (2) mendapatkan interval 
waktu aplikasi mikroorganisme lokal (MOL) yang terbaik pada pertumbuhan dan produksi padi sawah Metode SRI. Manfaat penelitian adalah untuk memberikan rekomendasi kepada petani tentang interval waktu aplikasi larutan MOL yang tepat pada tanaman padi sawah Metode SRI.

\section{METODE PENELITIAN}

Penelitian lapangan telah dilaksanakan di Desa Tara-Tara Dua Kecamatan Tomohon Barat Kabupaten Minahasa, selama 5 (lima) bulan, mulai Juli 2017 sampai dengan Desember 2017.

Bahan dan alat yang digunakan adalah : benih padi var. Ciherang, MOL daun gamal, kompos jerami, pestisida nabati, timbangan analitis, sprayer, dan lain-lainl. Kompos jerami dan MOL yang digunakan berasal dari produk yang dibuat atau diolah sendiri.

\section{Rancangan Percobaan}

Percobaan terdiri atas faktor tunggal, yang disusun dalam Rancangan Acak Kelompok (RAK). Faktor yang diteliti adalah interval waktu aplikasi MOL gamal, yang terdiri atas : 0 hari $\left(G_{1}\right), 5$ hari $\left(G_{2}\right), 10$ hari $\left(G_{3}\right), 15$ hari $\left(G_{4}\right)$, dan 20 hari $\left(G_{5}\right)$. Setiap perlakuan diulang tiga kali, sehingga terdapat 15 petak percobaan.

\section{Prosedur Kerja}

Pengolahan tanah dengan dibajak sedalam 25 - $30 \mathrm{~cm}$ sambil membenamkan sisa-sisa tanaman dan rumput-rumputan, bersamaan dengan itu dilakukan juga pemberian kompos jerami agar dapat tercampur dengan baik.

Persiapan dan persemaian benih dilakukan dengan memasukkan benih yang akan diuji ke dalam ember berisi larutan garam kemudian diaduk, pisahkan benih yang mengambang dengan yang tenggelam. Benih yang tenggelam adalah benih yang bermutu baik atau bernas, kemudian benih dicuci dengan air sampai bersih. Benih direndam selama 24 - 48 jam, kemudian diangkat dan dimasukkan ke dalam karung yang berpori dengan tujuan untuk memberikan udara masuk ke dalam benih padi, dan kemudian disimpan di tempat yang lembab. Penganginan dilakukan selama 24 jam (Veco Indonesia, 2007).

Persemaian dilakukan pada hamparan sawah untuk mempermudah penanaman. Campurlah tanah, pasir dan pupuk organik dengan perbandingan 1:1:1. Benih yang sudah dianginkan ini, ditaburkan ke petakan pembibitan yang sudah disiapkan.

Petak-petak percobaan dibuat dengan ukuran $3 \mathrm{~m} \times 4 \mathrm{~m}$, sebelum penanaman bibit terlebih dahulu dilakukan penyaplakan dengan memakai caplak agar jarak tanam lurus dan rapi, jarak tanam yang digunakan $30 \mathrm{~cm} \times 30 \mathrm{~cm}$. Bibit yang ditanam berumur 11 hari setelah semai yaitu ketika bibit mempunyai 2 helai daun, ditanam tunggal atau satu bibit per lubang pada kedalaman $1-1,5 \mathrm{~cm}$ dengan kondisi tanah sawah saat penanaman tidak tergenang air.

Pemberian MOL gamal dengan dosis 1 : 10 (MOL : air), waktu pemberian dimulai pada saat tanaman berumur 14 hari setelah pindah tanam dengan interval waktu pemberian sesuai perlakuan sampai tanaman memasuki masa pembungaan (60 hari).

Pemeliharaan tanaman, meliputi : pengendalian hama dan penyakit, penyiangan, dan pengelolaan air. Pengendalian hama dan penyakit dalam metode SRI dilaksanakan pengendalian hama secara terpadu (PHT). Pemberian air, dengan cara terputus-putus (intermitten) dengan ketinggian air di petakan sawah maksimum $1 \mathrm{~cm}$, paling baik macak-macak $(0,5 \mathrm{~cm})$. Pada periode tertentu petak sawah harus dikeringkan sampai pecah-pecah. Pemberian air terlalu tinggi akan menyebabkan pertumbuhan akar terganggu dan pertumbuhan tunas tidak optimal (Sampoerna, 2009). Panen dilakukan setelah tanaman tua ditandai dengan menguningnya bulir secara merata atau kadar air gabah sekitar 23-25\%.

\section{Variabel Pengamatan}

Variabel respon yang diamati, meliputi : (1) tinggi tanaman, diukur pada saat panen, (2) jumlah anakan produktif diukur pada saat panen, (3) jumlah gabah/malai, diukur pada saat panen, (4) bobot 1000 butir gabah kering panen, diukur setelah panen, (5) prosentase gabah bernas/ 
rumpun, (6) hasil gabah kering panen/petak, diukur setelah panen

\section{Analisis Data}

Semua variabel pengamatan diuji dengan analisis ragam dan jika terdapat perbedaan dilanjutkan dengan Uji Beda Nyata Terkecil (BNT) pada taraf uji $5 \%$.

\section{HASIL DAN PEMBAHASAN}

\section{Keadaan Umum Percobaan}

Keadaan pertanaman padi pada saat pindah tanam sampai umur 60 hst tidak ada serangan hama dan penyakit yang berarti. Setelah selesai penyemprotan MOL gamal, yaitu pada umur mendekati 70 hst terdeteksi mulai ada serangan hama yang terlihat daun-daun beberapa tanaman mulai menguning, dan akhirnya penyemprotan $\mathrm{MOL}$ gamal dilanjutkan lagi pada semua perlakuan untuk mengendalikan serangan hama, dan terbukti dapat mengendalikan serangan hama tersebut.

\section{Pertumbuhan dan Hasil Tanaman Padi Sawah}

Hasil analisis statistik menunjukkan bahwa perlakuan interval waktu aplikasi MOL daun gamal berpengaruh terhadap jumlah anakan produktif, jumlah gabah bernas/malai, jumlah gabah hampa/ malai, dan hasil gabah kering panen (GKP)/petak, namun tidak berpengaruh terhadap tinggi tanaman (Tabel 1).

Tinggi tanaman padi sawah tidak dipengaruhi oleh waktu aplikasi MOL daun gamal, hal tersebut disebabkan oleh faktor internal yaitu sifat genetik tanaman padi varietas Ciherang. Jumlah anakan produktif tertinggi dicapai pada interval waktu aplikasi MOL daun gamal setiap 5, 10, dan 15 hari sekali dengan nilai masing-masing 29,26 ; 29,30; dan 28,66 anakan, dan terendah pada perlakuan kontrol dan 20 hari sekali.

Jumlah gabah bernas/malai tertinggi dicapai pada perlakuan 15 hari dengan nilai 176,90 walaupun tidak berbeda dengan perlakuan 5 dan 10 hari, dengan nilai masing-masing 172,03 dan 171,97 . Sebaliknya, jumlah gabah hampa/malai terendah pada perlakuan 15 hari dengan nilai 19,8 dan tidak berbeda dengan perlakuan 10 dan 5 hari, dengan nilai masing-masing 20,77 dan 20,03. Jumlah gabah hampa tertinggi dicapai pada perlakuan 20 hari dan kontrol dengan nilai 22,0 dan 23,03. Hasil gabah kering panen (GKP) tertinggi dicapai oleh perlakuan 15 hari dengan nilai 9,50 $\mathrm{kg} /$ petak atau meningkat sebesar $20 \%$ dari perlakuan kontrol yang hanya mencapai $7,60 \mathrm{~kg} / \mathrm{petak}$.

Peningkatan pertumbuhan, komponen hasil maupun produksi padi sawah pada penelitian ini, diakibatkan oleh pemberian MOL gamal yang mengandung berbagai unsur hara, baik unsur makro maupun unsur mikro. Menurut Purwasasmita dan Sutaryat (2012), bahwa unsur hara yang terkandung dalam larutan $\mathrm{MOL}$ daun gamal adalah: pH (4,6\%), C/N (12), C (28,86\%), N (2,43\%), P2O5 $(0,04 \%), \mathrm{K} 2 \mathrm{O}(0,05 \%)$, S $(0,32 \%)$, Fe $(8,71 \mathrm{ppm})$, dan Zn (3,48 ppm).

Tabel 1. Pengaruh Waktu Aplikasi MOL Daun Gamal terhadap Tinggi Tanaman, Jumlah Anakan Produktif, Jumlah Gabah Bernas/malai, Jumlah Gabah Hampa/malai, dan Hasil GKP

(Table 1. Influence of Gliricidia MOL on Plant Height, Number of Productive Tillers, Number of Filled Grain/Panicle, Number of Empty Grain/Panicle and Grain Yield)

\begin{tabular}{lccccc}
\hline Perlakuan & $\begin{array}{c}\text { Tinggi Tanaman } \\
(\mathrm{cm})\end{array}$ & $\begin{array}{c}\text { Jumlah } \\
\text { Anakan } \\
\text { produktif }\end{array}$ & $\begin{array}{c}\text { Jumlah Gabah } \\
\text { Bernas/malai }\end{array}$ & $\begin{array}{c}\text { Jumlah Gabah } \\
\text { Hampa/malai }\end{array}$ & $\begin{array}{c}\text { Hasil GKP } \\
\text { (kg/petak) }\end{array}$ \\
\hline Kontrol $\left(\mathrm{G}_{1}\right)$ & 100,37 & $27,43 \mathrm{~b}$ & $164,03 \mathrm{c}$ & $23,03 \mathrm{a}$ & $7,60 \mathrm{c}$ \\
5 hari $\left(\mathrm{G}_{2}\right)$ & 100,33 & $29,26 \mathrm{a}$ & $172,03 \mathrm{ab}$ & $20,03 \mathrm{c}$ & $7,73 \mathrm{c}$ \\
10 hari $\left(\mathrm{G}_{3}\right)$ & 100,13 & $29,30 \mathrm{a}$ & $171,97 \mathrm{ab}$ & $20,77 \mathrm{bc}$ & $8,07 \mathrm{bc}$ \\
15 hari $\left(\mathrm{G}_{4}\right)$ & 99,27 & $28,66 \mathrm{ab}$ & $176,90 \mathrm{a}$ & $19,80 \mathrm{c}$ & $9,50 \mathrm{a}$ \\
20 hari $\left(\mathrm{G}_{5}\right)$ & 99,13 & $27,23 \mathrm{~b}$ & $168,67 \mathrm{bc}$ & $22,00 \mathrm{ab}$ & $8,73 \mathrm{~b}$ \\
\hline BNT $5 \%$ & - & 1,75 & 5,62 & 1,55 & 0,76 \\
\hline
\end{tabular}

Ket : Angka-angka yang diikuti oleh huruf yang sama, tidak berbeda nyata pada taraf uji BNT 5\%. 
Nitrogen dibutuhkan oleh tanaman padi dalam jumlah yang besar untuk digunakan pada fase pertumbuhan awal dan pada fase pembentukan anakan untuk meningkatkan jumlah malai. De Datta (1981) mengemukakan, bahwa fungsi unsur nitrogen pada pertumbuhan tanaman padi adalah : (1) meningkatkan jumlah klorofil pada daun sehingga daun berwarna hijau tua, (2) mendorong pembentukan anakan, (3) meningkatkan ukuran daun dan gabah, (4) meningkatkan jumlah gabah per malai, (5) meningkatkan prosentase gabah bernas, dan (6) meningkatkan kandungan protein pada beras.

Berbagai hasil penelitian menunjukkan bahwa larutan MOL dapat meningkatkan pertumbuhan dan produksi tanaman. Dilaporkan oleh Jamilah (2016), bahwa pemberian 20\% POC asal C.odorata yang diberikan setiap 3 minggu sekali dengan konsentrasi 20\% POC meningkatkan serapan hara kalium dan hasil gabah kering sebesar $11,14 \%$ dibandingkan dengan konsentrasi 10\% POC. Setianingsih (2009) dalam hasil penelitiannya pada tanaman padi, melaporkan bahwa perlakuan priming dengan pupuk organik cair $\mathrm{MOL}$ gamal dapat meningkatkan daya kecambah benih, keserempakan tumbuh, panjang akar, berat brangkasan basah dan berat brangkasan kering yang tinggi.

Mukhlis, dkk. (2012), menyatakan bahwa pemberian kombinasi MOL sayuran dan buahbuahan memberikan pertumbuhan yang paling efektif pada tanaman bawang merah. Demikian halnya Rahayu dan Ariyadi (2014) dalam percobaan tentang pengaruh kompos dan larutan MOL pada tanaman tomat, menunjukkan bahwa larutan MOL memberikan respon yang baik pada pertumbuhan tanaman tomat, dan MOL cebreng (gamal) memberikan angka tertinggi pada serapan $\mathrm{N}$ dan $\mathrm{K}_{2} \mathrm{O}$. Yuliani dan Syamsiah (2014) dalam percobaan tentang aplikasi beberapa jenis $\mathrm{MOL}$ pada tanaman Caisin menunjukkan bahwa perlakuan kombinasi $\mathrm{MOL}$ bonggol pisang dengan waktu pemberian 2 minggu sebelum tanam memiliki nilai bobot segar tertinggi yaitu $106,99 \mathrm{~g}$. Hasil penelitian Julita, $d k k$. (2013) tentang pemberian MOL nasi dan hormone tanaman unggul, menunjukkan bahwa pengaruh tunggal perlakuan MOL nasi berpengaruh pada umur berbunga, umur panen, berat buah per tanaman secara ekonomis dan berat buah per plot secara ekonomis dengan perlakuan terbaik 100 cc/lair.

\section{KESIMPULAN DAN SARAN}

\section{Kesimpulan}

Waktu aplikasi MOL daun gamal tidak berpengaruh pada tinggi tanaman, namun berpengaruh pada jumlah anakan produktif, jumlah gabah bernas/petak, jumlah gabah hampa/petak, dan hasil gabah kering panen (GKP)/petak.

Hasil terbaik dicapai oleh perlakuan aplikasi MOL gamal setiap 15 hari dengan jumlah gabah bernas/malai tertinggi (176,90 butir), jumlah gabah hampa/malai terendah (19,8 butir) dan hasil GKP tertinggi sebesar $9,50 \mathrm{~kg} /$ petak setara dengan 7,92 ton/ha atau meningkat sebesar $20 \%$ dari perlakuan kontrol yang hanya mencapai 7,60 $\mathrm{kg} /$ petak.

\section{Saran}

Berdasarkan pada hasil penelitian disarankan interval waktu aplikasi MOL gamal pada tanaman padi sawah adalah setiap 15 hari sejak tanaman berumur 14 HST sampai umur 70 hari HST.

\section{UCAPAN TERIMA KASIH}

Terima kasih disampaikan kepada Rektor Universitas Sam Ratulangi melalui Ketua LPPM yang telah memberikan dana penelitian yang dibiayai dari Daftar Isian Pelaksanaan Anggaran (DIPA) Nomor : SP DIPA-042.01.2.400959/2017 tanggal 21 April 2017.

\section{DAFTAR PUSTAKA}

Anugrah, I.S., Sumedi dan I Putu Wardhana. 2008. Gagasan dan Implementasi System of Rice Intensification (SRI) Dalam Kegiatan Budidaya Padi Ekologis (BPE). Analisis Kebijakan Pertanian Vol.16 No.1 Maret $2008: 75-99$. 
Badan Pusat Statistik. 2015. Sulawesi Utara Dalam Angka. http://www.bps.go.id. [15 Oktober 2016].

De Datta, S.K. 1981. Principles and Practices of Rice Production. John Wiley \& Sons. New York. $618 \mathrm{p}$.

Jamilah. 2016. Pengaruh Pupuk Organik Cair Asal C. odorata Terhadap Serapan Hara Kaliumdan Hasil Padi Ladang. Jurnal Bibiet 1(1) : 17-26, Maret 2016. http://ejournal.kopertis10.or.id.

Desember 2017].

Julita, S., H. Gultom dan Mardaleni. 2013. Pengaruh Pemberian Mikroorganisme Lokal Nasi dan Hormon Tanaman Unggul Terhadap Pertumbuhan dan Produksi Tanaman Cabai (Capsicum anuum L.). Jurnal Dinamika Pertanian Vol. XXVIII, No. 3 (167-174), Desember 2013. http://www.MOL.pdf. [20 November 2017].

Mukhlis, Purwaningsih dan D. Anggorowati. 2012. Pengaruh Berbagai Jenis MOL Terhadap Pertumbuhan dan Hasil Bawang Merah pada Tanah Aluvial. Skripsi S1. Fakultas Pertanian Universitas Tanjung Pura Pontianak. http://www.11.83-3817-1-PB. [2 Oktober 2016.

Purwasasmita, M. dan A. Sutaryat. 2012. Padi Sri Organik Indonesia. Penebar Swadaya. Jakarta.
Rahayu, S. dan E. B. Ariyadi. 2014. Pengaruh Kompos Lamtoro dan Larutan MOL Terhadap Pertumbuhan dan Hasil Tomat (Lycopersicum esculentum). http://www.digilib.unila.ac.id. $\quad[12$ Mei 2016].

Sampoerna. 2009. Teknik dan Budidaya Penanaman Padi System of Rice Intensification (SRI). Pusat Pelatihan Kewirausahaan Sampoerna. Desa Gunting Kec. Sukorejo Kab. Pasuruan. www.indoSampoernaManual09.pdf. [2 Desember 2017].

Setianingsih, R. 2009. Kajian Pemanfaatan Pupuk Organik Cair MOL dalam Priming, Umur Bibit dan Peningkatan Hasil Tanaman Padi (Oryza sativa L.) (Uji Coba Penerapan SRI). Tesis Prodi Agronomi Program Pascasarjana Universitas Sebelas Maret Surakarta. http://wwwcore.ac.uk/download. [23 Agustus 2017].

Veco Indonesia. 2007. Menembus Batas Kebuntuan Produksi : Cara SRI Dalam Budidaya Padi. http://www.indoveco Manual07.pdf. [2 Desember 2016].

Yuliani dan M. Syamsiah. 2014. Pengaruh Aplikasi Pemberian Beberapa Jenis MOL Terhadap Produksi Tanaman Caisin. http://www.lppm.unsur.ac.id. $\quad[12$ September 2017]. 